\title{
Komplexní magmaticko-hydrotermální vývoj columbitu, mikrolitu a fersmitu z beryl-columbitového pegmatitu D6e u Maršíkova, Česká republika
}

\section{Complex magmatic to hydrothermal evolution of columbite, microlite and fersmite from beryl-columbite D6e pegmatite near Maršíkov, Czech Republic}

\author{
ŠttěPÁn ChLÁdeK ${ }^{1) *}$ a PaVel UheR ${ }^{2)}$ \\ 1)Katedra geologického inženýrství, Hornicko-geologická fakulta, VŠB - Technická univerzita Ostrava, 17. listopadu 15, \\ 70833 Ostrava-Poruba, Česká republika; *e-mail: st.chladek@seznam.cz \\ ${ }^{2}$ Katedra mineralógie a petrológie, Prírodovedecká fakulta, Univerzita Komenského, Ilkovičova 6, 84215 Bratislava, \\ Slovenská republika
}

CHLÁDEK Š, UHER P (2020) Komplexní magmaticko-hydrotermální vývoj columbitu, mikrolitu a fersmitu z beryl-columbitového pegmatitu D6e u Maršíkova, Česká republika. Bull Mineral Petrolog 28(1): 23-34 ISSN 2570-7337

\begin{abstract}
The recently rediscovered small D6e granitic pegmatite body, enclosed in amphibole gneiss of the Sobotín amphibolite massif (Jeseníky Mountains, Czech Republic), is characterized by numerous accessory minerals, including common columbite group minerals (CGM) and minor microlite and fersmite related to blocky K-feldspar unit. The CGM show complex internal zoning. Primary magmatic columbite-(Mn) occurs as corroded domains of prevailing homogeneous pattern, followed by less evolved oscillatory zonation. Primary CGM were overprinted by extensive recrystallization controlled by late-magmatic to post-magmatic fluids and leading to a formation of complex patchy and convolute oscillatory domains of secondary (hydrothermal) CGM. Primary columbite-(Mn) shows significantly limited $\mathrm{Ta} /(\mathrm{Ta}+\mathrm{Nb})$ and $\mathrm{Mn} /(\mathrm{Mn}+\mathrm{Fe})$ ratios, whereas secondary columbite-(Fe) to -(Mn) show slightly wider Fe-Mn and Nb-Ta compositional variations. Complex textures and the element fluctuations indicate a partial dissolution-reprecipitation of primary CGM caused by late- to post-magmatic fluids. Moreover, late calciomicrolite I, II and fersmite precipitated on the cracks of columbite crystals. Rare U-rich calciomicrolite I was extensively replaced by fersmite and oscillatorily zoned U-poor calciomicrolite II, slightly enriched in F. Their formation sequestrated part of hydrothermally released $\mathrm{Na}, \mathrm{Ca}, \mathrm{U}$ and represents the final subsolidus fluid-driven stage of the pegmatite evolution. Textural and compositional variations of $\mathrm{Nb}$-Ta mineralization point to a complex magmatic to hydrothermal evolution of the D6e beryl-columbite pegmatite similar to other pegmatites in this region.
\end{abstract}

Key words: columbite, microlite, fersmite, granitic pegmatite, magmatic fractionation, subsolidus alteration, dissolution-reprecipitation

Obdrženo 17. 12. 2019; prijiato 16. 3. 2020

\section{Úvod}

Niob a zejména tantal představují nenahraditelnou součást mnoha tzv. „high“ technologií. V souběhu stále zvyšující se jejich poptávky a relativně limitované distribuce $v$ horninách zemské kůry se stávají kritickými kovy 21. století. $Z$ velké škály akcesorických oxidických minerálů $\mathrm{Nb}$ a Ta dosahuje největšího významu skupina columbitu (CGM). Texturně i chemicky různorodá skupina columbitu je z hlediska krystalochemie a paragenetického vystupování považována za významný ukazatel geochemického vývoje jejich mateřských hornin, a to především frakcionovaných granitoidních komplexů a $\mathrm{k}$ nim geneticky přidružených vzácnoprvkových pegmatitů (např. Černý et al. 1985, 1986; Ercit 1994; Chudík et al. 2011; Badanina et al. 2015; Melcher et al. 2015; Van Lichtervelde et al. 2018). Alterací primárních magmatických CGM, ale také např́klad wodginitu, rutilu, wolframitu, fluidy pestré geneze vzniká různorodá paleta rekrystalizačních produktů (např. sekundární CGM, su- perskupina pyrochloru, fersmit, ixiolit), dokumentující post-magmatickou historii vývoje jejich mateřských hornin (Geisler et al. 2004; Van Lichtervelde et al. 2007; Neiva et al. 2015; Duran et al. 2016).

Vzácnoprvkové pegmatity beryl-columbitového subtypu (ve smyslu Černého, Ercita 2005; Nováka 2005) v oblasti Maršíkova v sileziku Českého masivu, vyznačující se relativně hojnou prítomností $\mathrm{Nb}$-Ta mineralizace, byly v minulosti studovány řadou autorů (např. Pokorný, Staněk 1951; Dostál 1966; Novák 1988; Novák, Rejl 1993; Zimák 2013), zájmová mineralizace potom například Černým et al. (1992, 1995) (Schinderhübel I, II, III), Novákem et al. (2003) (Scheibengraben) a nejnověji Chládkem a Zimákem (2016) (Lysá hora). Tato práce charakterizuje proměny $\mathrm{Nb}$-Ta mineralizace (CGM, mikrolit, fersmit) během magmatické etapy vývoje mateřského pegmatitu (D6e) a dále poukazuje na fenomén jeho rozsáhlé postmagmatické alterace a rekrystalizace. 

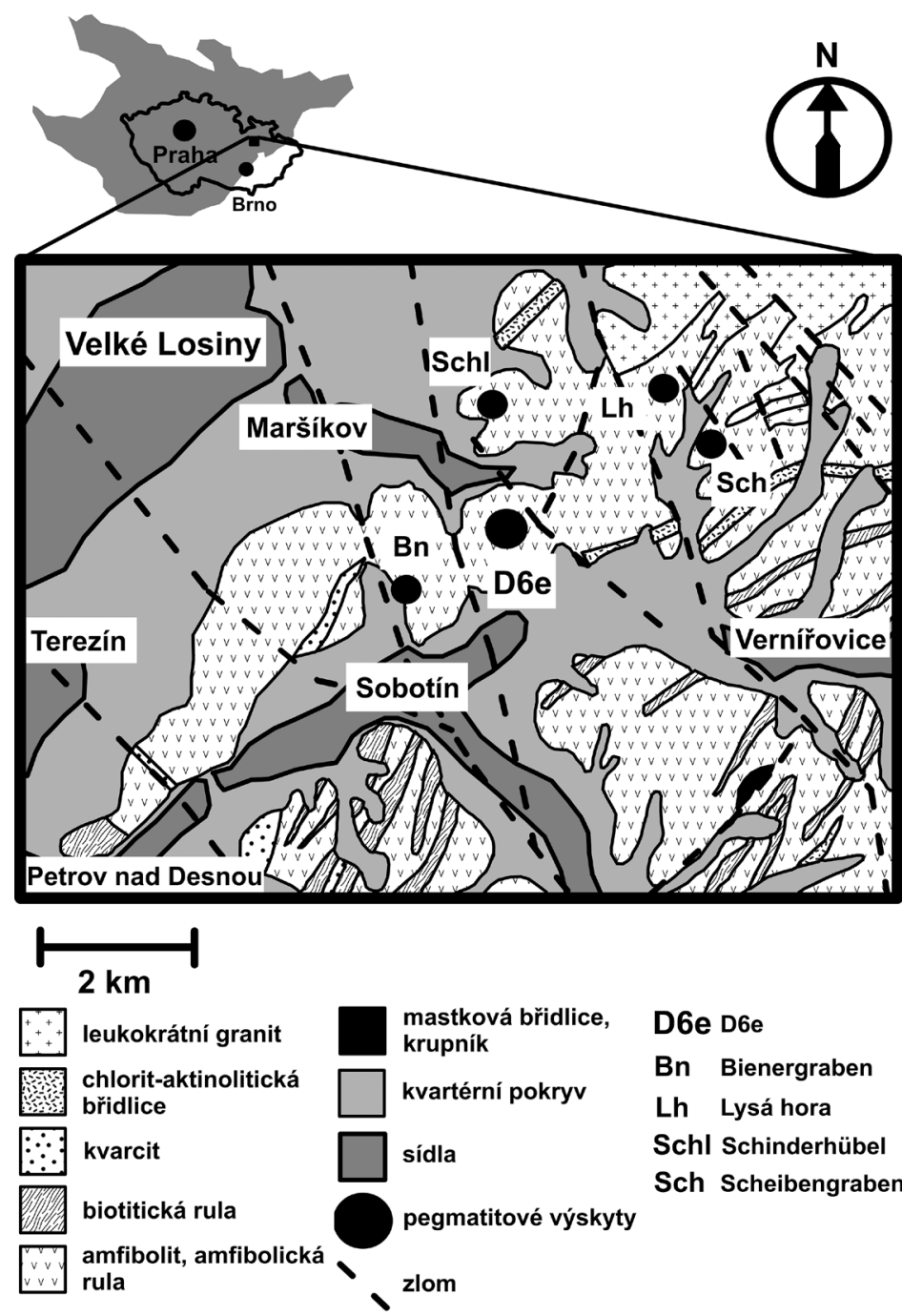

Obr. 1 Geologická mapa oblasti Maršíkova s vyznačením pegmatitu D6e a dalších berylových pegmatitů oblasti. Kompilováno na základě Geologické mapy České republiky 1:500 000 (Cháb et al. 2007 a on-line mapová aplikace České geologické služby 2019, upraveno).

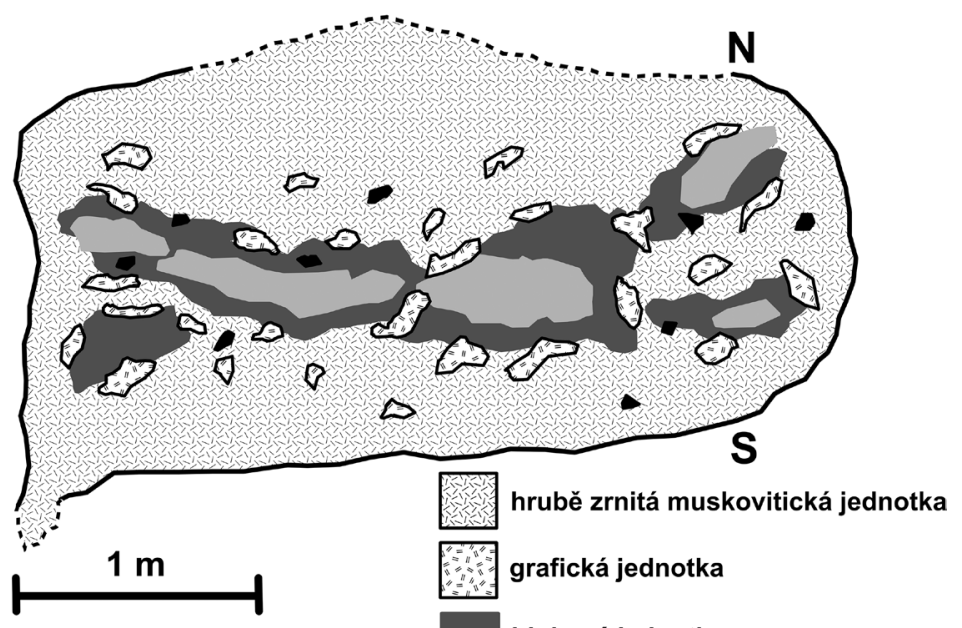

bloková jednotka

amfibolická rula

křemenné jádro

aplitická jednotka

jednotka cleavenlanditu

Obr. 2 Idealizovaný a zjednodušený řez pegmatitovým tělesem Maršíkov, D6e.

\section{Geologická situace}

Silezikum, reprezentující severovýchodní okraj Českého masivu, je tradičně chápáno jako komplex vyznačující se složitou příkrovovou stavbou, budovaný pre-devonskými krystalinickými jednotkami a variským metavulkanosedimentárním obalem (Kröner et al. 2000; Schulmann, Gayer 2000; Janoušek et al. 2014; Schulmann et al. 2014). Uvedený komplex byl pronikán karbonskými až raně permskými granitoidními intruzemi (např. Zachovalová et al. 2002) a na ně vázaným bohatým aplit-pegmatitovým doprovodem. Věk zájmových berylcolumbitových pegmatitů silezika není prímo znám, může být odvozen od geochemicky i mineralogicky blízkého pegmatoidního leukogranitu Čertovy kameny u Jeseníku (U-Pb datování na zirkonu - 334 Ma; Hegner, Kröner 2000). Uvedený věk je blízký dalším granitovým plutonům sousedícím s lugickou (sudetskou) zónou a budujícím východní okraj Českého masívu ( 350 až 330 Ma; např. plutony Kłodzko-Złoty Stok, Strzelin, Kudowa; Mikulski et al. 2013). Zájmový pegmatit D6e, podobně jako okolní berylcolumbitové pegmatity u Maršíkova a Sobotína, je uložen $v$ okolních biotit-amfibolických rulách sobotínského amfibolitového masívu (obr. 1).

\section{Vnitřní stavba a mineralogie pegmatitu}

$V$ nedávné době opětovně lokalizované menší těleso berylového pegmatitu $\mathrm{D} 6 \mathrm{e}$ je situováno na jihozápadním svahu bezejmenné kóty $565 \mathrm{~m} \mathrm{n}$. m., v zalesněném svahu nedaleko rozcestí silnice Sobotín - Maršíkov. GPS lokalizace daného výskytu jsou N 5001'43.4" a $E$ $17^{\circ} 05^{\prime} 8.1^{\prime \prime}$. Stručnou zmínku o pegmatitu prináší zpráva mapovacího týmu K. Paděry, Z. Pouby a kol., v níž je tento pegmatit pro pracovní účely označen jako D6e (Krut'a et al. 1968). Samotné pegmatitové těleso je situováno u paty agrárního valu a je pod něj částečně zanořené. Granitový pegmatit D6e tvoří čočka nepravidelného tvaru o odkrytých rozměrech cca $3.5 \times 2.5$ m při zachované pravé mocnosti $1-1.5 \mathrm{~m}$. Kontakt s okolní amfibolickou rulou je ostrý. Uvedený pegmatit je konformní s okolní foliací rul a mírně deformovaný, ale nemetamorfovaný. Jeho vnitřní stavba je nepravidelná, nicméně vykazuje určitý stupeň uspořádání texturně-paragenetických pegmatitových jednotek (obr. 2) od okraje k jádru tělesa: aplitická jednotka (křemen + K-živec + albit + biotit); podřadně vyvinutá grafická jednotka (K-živec + křemen); objemově dominantní (cca $70 \%$ objemu tělesa) muskovitická, hrubě zrnitá jednotka (křemen + K-živec + albit + muskovit \pm biotit \pm beryl); blokový K-živec (K-živec + křemen + muskovit + beryl) a křemenné jádro (obr. 2). Typické je uplatnění albitizace zejména $v$ hrubě zrnité, muskovitem bohaté jednotce a blokovém K-živci, nicméně samostatná jednotka charakteru cukrovitého albitu, která na mnoha okolních výskytech rozsáhle nahrazuje jiné jednotky pegmatitu, není vyvinuta. Jednotka cleavelanditu (albit + muskovit) tvoří nepatrné smouhy cm rozměrů $v$ hrubě zrnité a blokové jednotce. 
Tabulka 1 Přehled známých minerálů z pegmatitu D6e a srovnání s dalšími pegmatity zájmové oblasti.

\begin{tabular}{|c|c|c|c|c|c|}
\hline & Scheibengraben & Schinderhübel & Bienergraben & Lysá hora & D6e \\
\hline křemen & $\mathrm{XXX}$ & $\mathrm{XXX}$ & $\mathrm{XXX}$ & $X X X$ & $\overline{X X X}$ \\
\hline K-živec & $X X X$ & $X X$ & $X X X$ & $X X X$ & $X X X$ \\
\hline albit & $X X$ & $X X$ & $X X$ & $X X$ & $\mathbf{X X}$ \\
\hline muskovit & $X X X$ & $X X X$ & $X X X$ & $X X X$ & $X X X$ \\
\hline biotit & $X$ & $X$ & X & $X X$ & $\mathrm{X}$ \\
\hline almandin-spessartin & $X X$ & $X X$ & $X X$ & $X X$ & $\mathbf{X X}$ \\
\hline skoryl & $X X$ & & & & \\
\hline gahnit & $X X$ & $X X$ & $\mathrm{X}$ & & \\
\hline zirkon & $X$ & $x$ & $\mathrm{X}$ & $\mathrm{X}$ & $x$ \\
\hline beryl & $X X$ & $x$ & $\mathrm{x}$ & $\mathrm{x}$ & $X X$ \\
\hline bavenit & $\mathrm{X}$ & $\mathrm{x}$ & $\mathrm{X}$ & & $X X$ \\
\hline milarit & $x$ & & & & $X X$ \\
\hline bertrandit & $\mathrm{x}$ & & & & $\mathrm{X}$ \\
\hline euklas & $\mathrm{X}$ & & & & \\
\hline chrysoberyl & $\mathrm{x}$ & & & & \\
\hline fluorapatit & $\mathrm{x}$ & $\mathrm{x}$ & $\mathrm{x}$ & $\mathrm{x}$ & $\mathrm{x}$ \\
\hline sillimanit & $\mathrm{X}$ & & & & \\
\hline topaz & $\mathrm{X}$ & & & & \\
\hline monazit-(Ce) & $\mathrm{X}$ & $\mathrm{X}$ & $\mathrm{X}$ & $\mathrm{X}$ & \\
\hline cheralit & & $\mathrm{x}$ & & $\mathrm{X}$ & \\
\hline xenotim- $(Y)$ & & & & $\mathrm{X}$ & \\
\hline triplit & $\mathrm{X}$ & & & & \\
\hline uraninit & $\mathrm{X}$ & $\mathrm{X}$ & $\mathrm{X}$ & $\mathrm{X}$ & $\mathrm{x}$ \\
\hline coffinit & & & & $X$ & \\
\hline CGM & $X X$ & $X X$ & $\mathrm{X}$ & $X X$ & $X X$ \\
\hline ixiolit & $X$ & $X$ & & & \\
\hline rutil & $\mathrm{X}$ & $\mathrm{x}$ & $\mathrm{X}$ & $\mathrm{X}$ & \\
\hline tapiolit-(Fe) & $\mathrm{X}$ & & & & \\
\hline titanit & & $\mathrm{X}$ & & & $\mathrm{X}$ \\
\hline skupina pyrochloru & $\mathrm{X}$ & $\mathrm{X}$ & $\mathrm{X}$ & $\mathrm{X}$ & \\
\hline skupina mikrolitu & $\mathrm{x}$ & $\mathrm{x}$ & $\mathrm{x}$ & & $x$ \\
\hline aeschynit-(Ce) & & & & $\mathrm{X}$ & \\
\hline fersmit & $\mathrm{X}$ & $\mathrm{X}$ & & & $\mathbf{x}$ \\
\hline rynersonit & $\mathrm{X}$ & $\mathrm{X}$ & & $\mathrm{X}$ & \\
\hline epidot & $\mathrm{X}$ & $X$ & & & $X$ \\
\hline chlorit & $X$ & $X$ & $\mathrm{X}$ & $\mathrm{X}$ & $X$ \\
\hline hematit & $X$ & $X$ & $\mathrm{X}$ & $X$ & $X$ \\
\hline bismut & $X$ & $X$ & $X$ & & \\
\hline bismutit & $X$ & $X$ & $\mathrm{X}$ & & \\
\hline pyrit & $x$ & $X$ & & $X$ & $X$ \\
\hline
\end{tabular}

Pozn. zkratky: XXX - hojný, XX - minoritní, X - vzácný minerál, tučně zvýrazněny úzce asociující minerály s $\mathrm{Nb}$-Ta mineralizací pegmatitu D6e.

Mineralogie pegmatitového tělesa zahrnuje kromě horninotvorných minerálů celou řadu akcesorických minerálů, např́iklad granát, beryl, columbit a sekundární bavenit (Krut'a et al. 1968). Nověji byl mimo výše uvedené minerály zjištěn také: fersmit, mikrolit, další sekundární Be-minerály a jiné fáze (tab. 1). Kř́ídově bílý bavenit tvoří lupenité a tabulkovité agregáty až $3 \times 3 \mathrm{~cm}$ velké, především $v$ hrubě zrnité jednotce. $\vee$ trhlinách a dutinkách $v$ silně albitizovaných partích blokového K-živce a hrubě zrnité jednotky byl hojně zjištěn milarit, vyskytující se ve formě bělavých až nažloutlých skelně lesklých sloupcovitých krystalů o délce až $2 \mathrm{~cm}$ anebo stébelnatých krystalů o délce až $5 \mathrm{~cm} v$ asociaci s albitem, epidotem, křemenem aj., dále byl zjištěn společně s produkty postmagmatické alterace primárního berylu (sekundární beryl, bertrandit, K-živec, albit, muskovit). Mikroskopicky byly identifikovány také uraninit a fluorapatit. Makroskopický zirkon tvoří dipyramidální krystaly o velikosti až $5 \mathrm{~mm}$. Na trhlinách $v$ príkontaktních partiích pegmatitového tělesa $v$ hrubě zrnité jednotce a dále $v$ dutinách a pseudomorfózách po primárním berylu, spolu se sekundárními Beminerály, byly zjištěny například K-živec, albit, křemen, epidot a další minerály (tab. 1).
Tabulka 2 EPMA-analytické podmínky pro měřené $\mathrm{Nb}$-Ta minerály.

\begin{tabular}{|c|c|c|c|c|}
\hline prvek & linie & standard & CGM & PSGM, fersmit \\
\hline $\mathrm{W}$ & $L \alpha$ & $\mathrm{CaWO}_{4}$ & $1279-1377$ & 1311-1418 \\
\hline $\mathrm{Nb}$ & $L \alpha$ & $\mathrm{LiNbO}_{3}$ & $886-964$ & $730-825$ \\
\hline $\mathrm{Ta}$ & $L \alpha$ & $\mathrm{LiTaO}_{3}$ & 1163-1269 & $1191-1297$ \\
\hline $\mathrm{Ti}$ & $K \alpha$ & $\mathrm{TiO}_{2}$ & $431-486$ & $460-518$ \\
\hline $\mathrm{Zr}$ & $L \beta$ & $\mathrm{ZrO}_{2}$ & $669-765$ & $674-768$ \\
\hline U & $M \beta$ & $\mathrm{UO}_{2}$ & $655-967$ & $778-880$ \\
\hline Th & $M a$ & $\mathrm{ThO}_{2}$ & - & $582-633$ \\
\hline $\mathrm{Sb}$ & $L \alpha$ & $\operatorname{lnSb}$ & - & $359-384$ \\
\hline $\mathrm{Al}$ & $K \alpha$ & $\mathrm{Al}_{2} \mathrm{O}_{3}$ & - & $262-316$ \\
\hline $\mathrm{Ce}$ & $L \alpha$ & $\mathrm{CePO}_{4}^{3}$ & - & $1437-1665$ \\
\hline $\mathrm{Fe}$ & $K \alpha$ & fayalit & $567-610$ & $569-625$ \\
\hline $\mathrm{Mn}$ & $K a$ & rodonit & $527-586$ & $548-609$ \\
\hline $\mathrm{Mg}$ & $K a$ & forsterit & $255-284$ & $244-294$ \\
\hline $\mathrm{Zn}$ & $K \alpha$ & willemit & $893-963$ & $738-788$ \\
\hline $\mathrm{Ca}$ & $K \alpha$ & wollastonit & $195-208$ & $196-219$ \\
\hline $\mathrm{Na}$ & $K a$ & albit & - & $438-608$ \\
\hline$F$ & $K \alpha$ & $\mathrm{CaF}_{2}$ & - & $593-618$ \\
\hline
\end{tabular}



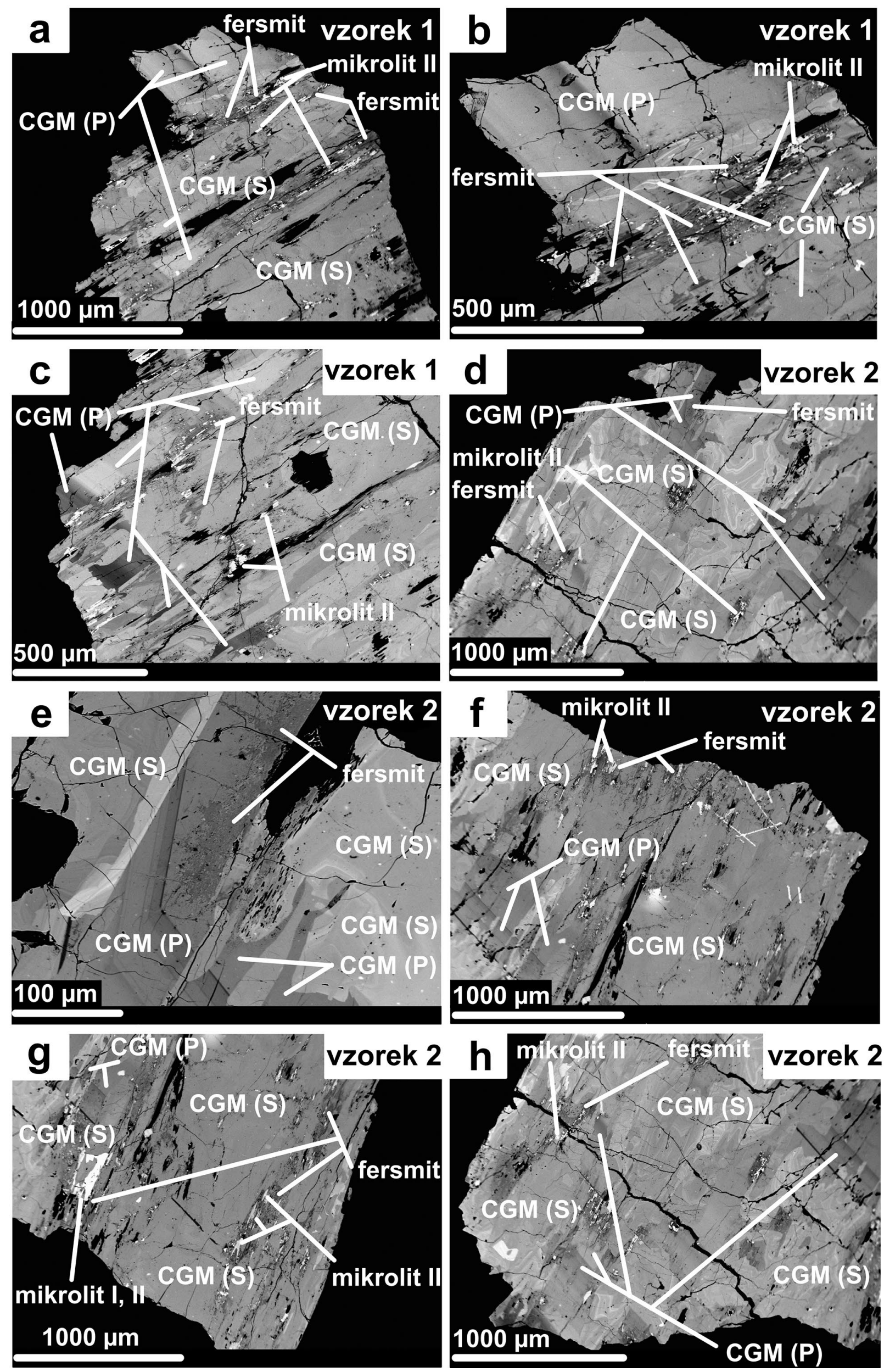


\section{Metodika}

Vzorky minerálů Nb-Ta byly odebrány z albitizované blokové jednotky K-živce a využity ke zhotovení leštěných nábrusů a studovány ve snímcích ve zpětně odražených elektronech (BSE). Chemické složení uvedených minerálů bylo zkoumáno metodou elektronové mikroanalýzy (přístroj Cameca SX100) ve vinově disperzním módu (WDX) ve Státním geologickém ústavu Dionýza Štúra v Bratislavě. Uvedené vzorky byly studovány za následujících analytických podmínek: průměr svazku 1 - $2 \mu \mathrm{m}$, urychlovací napětí $15 \mathrm{kV}$, vzorkový proud $20 \mathrm{nA}$, za využití přírodních i syntetických standardů (tab. 2). Data byla redukována využitím procedury PAP (Pouchou, Pichoir 1985). Empirické vzorce CGM byly kalkulovány na bázi 12 kationtů a 24 kyslíků s rozpočítáním nábojové bilance $\mathrm{Fe}^{2+}$ vs. Fe ${ }^{3+}$ dle procedury Ercita (1994), fersmit na bázi 6 kyslíků. Mikrolit byl normalizován na $\Sigma B(\mathrm{~W}+\mathrm{Nb}+\mathrm{Ta}+\mathrm{Ti}+-$ $\mathrm{Fe}^{3+}$ ) $=2$ (Atencio et al. 2010) a $\mathrm{Fe}_{\text {tot }}$ je uvažováno jako $\mathrm{Fe}^{3+}$, vstupující do pozice $B$ (Atencio et al. 2010; Christy, Atencio 2013); Al, v prípadě mikrolitu, je považován za kontaminaci (patrně minerální inkluze) a není zahrnut do jeho vzorce.

\section{Výsledky}

\section{Parageneze a vnitřní zonálnost Nb-Ta mineralizace}

CGM zarůstají do silně albitizovaných zrn K-živce $v$ asociaci s křemenem, místy intimně asociuji s krystaly berylu, zirkonem a granátem almandin-spessartinového složení (tab. 1). CGM tvoří tence až tlustě tabulkovité, kovově lesklé, tmavé, téměř černé krystaly anebo korodovaná zrna o velikosti až $4 \times 1.5 \times 1 \mathrm{~cm}$, často $\mathrm{v}$ asociaci $s$ většími krystaly berylu (ojediněle až $15 \times 10 \times 10 \mathrm{~cm}$ ). $\checkmark$ BSE obraze Ize rozlišit následující typy vnitřní zonálnosti (obr. 3 - 4): (i) primární (reliktní), poměrně homogenní textura, přecházející do nevýrazné difúzní zonality (obr. $3 a-h$ ), lokálně s vývojem jemně oscilační zonality (obr. 3c, e); (ii) sekundární rekrystalizační zonalita, reprezentovaná jednak převládajícím typem nepravidelné skvrnité textury (,patchy zoning“; obr. 3a - c, e - h; 4d - h), hojně je přitomna také konvoluční oscilační zonalita (obr. $3 a-b$, $3 d-e, 3 h, 4 a-c, 4 e)$.

Krystaly columbitu jsou běžně prostoupeny trhlinami, do nichž krystalovaly sekundární minerály skupiny mikrolitu, doprovázené četným fersmitem a způsobily lokální rekrystalizaci primárních CGM. Nepravidelné domény s vývojem sekundárních CGM, fersmitu a mikrolitu se často vyznačují početnými mikroskopickými póry a trhlinami (obr. 3a - h, 4a, 4c - h). Dokumentovaný vývoj mikrolitu je dvougenerační, zahrnující výjimečně zachované a značně korodované reliktní domény homogenního mikrolitu I, které jsou intenzívně prostupovány, zatlačovány a lemovány mikrolitem II (obr. 4h). Ve většině prípadů byl zjištěn pouze mikrolit II, tvořící oscilačně zonální krystaly, které jsou hojně doprovázeny agregáty fersmitu (obr. 3a - $h, 4 a, 4 c-h)$. Ojediněle byly zjištěny extrémně korodované relikty CGM uvnitř mikrolitových zrn (obr. 4h).

\section{Chemické složení Nb-Ta minerálů}

\section{Skupina columbitu}

Primární CGM chemismem náleží columbitu-(Mn) s $\mathrm{Mn} /(\mathrm{Mn}+\mathrm{Fe})=0.50-0.67 \mathrm{a} \mathrm{Ta} /(\mathrm{Ta}+\mathrm{Nb})=0.16-0.36(\mathrm{tab}$. 3a a 4; obr. 5). Složení sekundárních CGM odpovídá kromě převládajícího columbitu-(Mn) ojediněle také columbitu-(Fe) s širším intervalem $\mathrm{Mn} /(\mathrm{Mn}+\mathrm{Fe})=0.36-0.64$ a $\mathrm{Ta} /(\mathrm{Ta}+\mathrm{Nb})=0.25-0.50$ (tab. 4 ; obr. 5 ). Texturně a geneticky odlišné columbitové generace se vyznačují blízkými a poměrně nízkými obsahy minoritních prvků (tab. 3a); obsah Ti dosahuje $\leq 1.4 \mathrm{hm}$ \% $\mathrm{TiO}_{2}$ (0.27 apfu Ti), $\mathrm{Zr} \leq$ $0.6 \mathrm{hm} . \% \mathrm{ZrO}_{2}\left(0.08\right.$ apfu $\mathrm{Zr}$ ) a W $\leq 0.35 \mathrm{hm} . \% \mathrm{WO}_{3}(0.02$ apfu W). Vypočtené hodnoty $\mathrm{Fe}^{3+}$ jsou vysoce variabilní ve všech texturních typech ( $3 \mathrm{hm} . \% \mathrm{Fe}_{2} \mathrm{O}_{3} ; 0.60$ apfu $\mathrm{Fe}^{3+}$ ). Jediná známá diference $v$ obsahu minoritních prvků v primárních a sekundárních CGM byla zjištěna v případě U a Mg (tab. 3a). Primární CGM obsahují až 0.6 hm.\% $\mathrm{UO}_{2}$ (0.035 apfu U), zatímco druhý typ CGM obsahuje maximálně $0.1 \mathrm{hm} . \%$ UO (0.008 apfu U). Primární CGM obsahují $\leq 0.3 \mathrm{hm} . \% \mathrm{MgO}(0.11 \mathrm{apfu} \mathrm{Mg})$ a sekundární CGM vykazují obdobné hodnoty s lokálním zvýšením až k 0.45 hm.\% MgO (0.18 apfu Mg). Obsahy Sn, Sc, Y a Zn jsou na mezi detekce.

\section{Minerály skupiny mikrolitu a fersmit}

Reliktní domény mikrolitu I vykazuji $\mathrm{Ta} /(\mathrm{Ta}+\mathrm{Nb})=0.79$ - 0.80 a hojnější mikrolit II se vyznačuje $\mathrm{Ta} /(\mathrm{Ta}+\mathrm{Nb})=0.72$ - 0.84 (tab. 3b a 4). Mikrolit I obsahuje $\leq 53 \mathrm{hm}$. \% $\mathrm{Ta}_{2} \mathrm{O}_{5}$ (1.14 apfu Ta), zatímco v mikrolitu II obsah Ta roste až k 61 hm.\% $\mathrm{Ta}_{2} \mathrm{O}_{5}$ (1.32 apfu Ta; tab. 3b). Obsahy Nb jsou $v$ obou genetických typech blízké $\left(\leq 13.9 \mathrm{hm}\right.$. \% Ta $\mathrm{Ta}_{5}$; 0.51 apfu Ta). Mikrolit I je obohacen Ti ( $\leq 7.2$ hm. \% TiO; 0.42 apfu Ti) vzhledem k pozdějšímu typu II ( $\leq 5.1 \mathrm{hm}$. \% $\mathrm{TiO}_{2} ; 0.31$ apfu Ti). Tantal je tak dominantním kationem převládající valence $\mathrm{R}^{5+} \mathrm{v}$ pozici $B$ a všechna analyzovaná místa spadají do kompozičního pole mikrolitu (obr. $6 a)$. Celkové Fe je v př́padě všech studovaných mikrolitů vzhledem $\mathrm{k}$ relativně nižším proporcím předpokládáno jako $\mathrm{Fe}^{3+}\left(\leq 4.4 \mathrm{hm} . \% \mathrm{Fe}_{2} \mathrm{O}_{3} ; 0.25\right.$ apfu $\left.\mathrm{Fe}^{3+}\right)$, vstupující do pozice $B$. Pozice $A$ struktury mikrolitu se vyznačuje převládající valencí $\mathrm{R}^{2+}$, kde Ca je dominantním kationtem (obr. 6b). Zatímco mikrolit I má obsahy Ca snížené (s

Obr. 3 BSE snímky Nb-Ta oxidických minerálů z pegmatitu Maršíkov, D6e: a - Homogenní a vzácně oscilačně zonální domény primárního columbitu-(Mn) intenzívně rekrystalizované sekundárními nepravidelně zonálními CGM, na trhlinách kalciomikrolit Il a fersmit. $\boldsymbol{b}$ - Detail obr. 3a. Výskyt sekundárních konvolutně oscilačně zonálních CGM nahrazujících primární homogenní domény CGM. c - Nepravidelně zonální sekundární CGM obklopující korodované reliktní domény columbitu-(Mn), na trhlinách kalciomikrolit II a fersmit. $\boldsymbol{d}$ - Konvolutně oscilačně zonální sekundární CGM intenzívně nahrazující relikty primární oscilační růstové zonality, na trhlinách kalciomikrolit II a fersmit. e - Detail obr. 3d. Nepravidelně až konvolutně oscilačně zonální sekundární CGM nahrazující reliktní primární oscilačně zonální columbit-(Mn) a fersmit nahrazující CGM. $f$ - Nepravidelně zonální CGM nahrazující relikty primárního columbitu-(Mn), kalciomikrolit II a fersmit na trhlině CGM. $\mathbf{g}$ - Reliktní primární CGM, nahrazované sekundárními CGM, na trhlině dvougenerační vývoj mikrolitu (I a II) v asociaci s fersmitem. $\boldsymbol{h}$ - Reliktní domény primární oscilační zonality nahrazené nepravidelně až konvolutně oscilačně zonálními CGM, na trhlině kalciomikrolit II $v$ asociaci s fersmitem. 

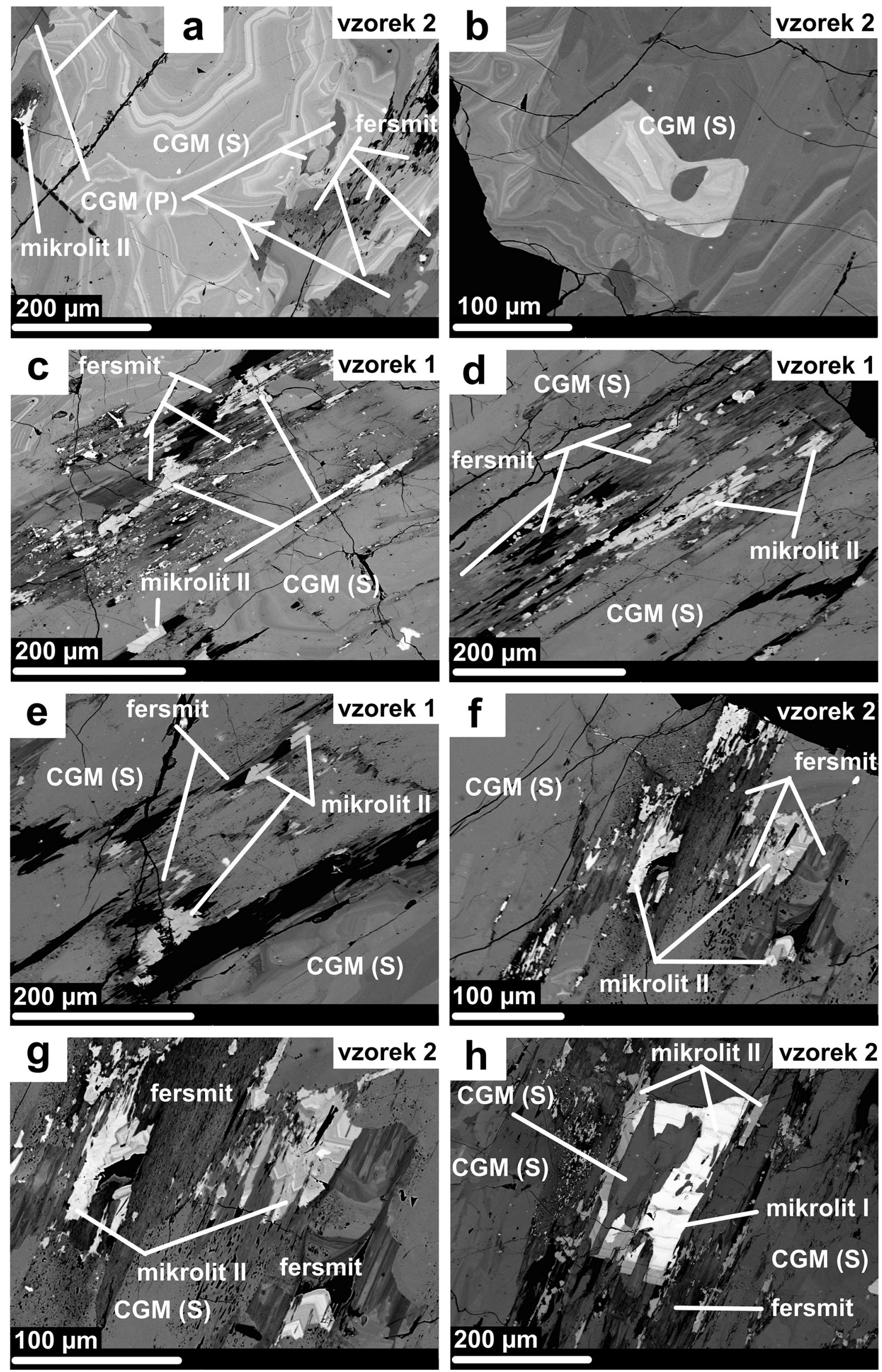
12.5 hm. \% CaO; 1.19 apfu Ca) a zvýšený U ( $\leq 19$ hm. \% $\mathrm{UO}_{2} ; 0.34$ apfu U), mikrolit II obsahuje $\leq 18 \mathrm{hm}$. \% CaO (1.55 apfu $\left.\mathrm{Ca}^{2+}\right)$, ale výrazně nižší obsah $\mathrm{U}(\leq 2.7 \mathrm{hm}$. \% $\mathrm{UO}_{2} ; 0.05$ apfu U). Lokálně bylo zjištěno v mikrolitu I a II až $1.8 \mathrm{hm}$.\% Na $\mathrm{Na}_{2}(0.3$ apfu $\mathrm{Na}$ ). Pod $0.8 \mathrm{hm} . \%$ oxidu dosahují koncentrace $\mathrm{Zr}$, Si a Ce. Na mezi detekce jsou Th, Sb, Sc a Mg. Typ II může obsahovat až $1.45 \mathrm{hm}$. \% F (0.37 apfu F). Skupina s nulovým nábojem (zahrnující EPMA neanalyzovatelný obsah $(\mathrm{OH})^{-}, \mathrm{H}_{2} \mathrm{O}$ anebo vakantní prostor) dominuje nad valenčními skupinami pozice $A$ pouze $v$ prípadě jednoho analyzovaného bodu mikrolitu I (patrně přechodného členu - tab. 3b). V ostatních případech skupina s nulovým nábojem $\vee$ pozici $A$ dosahuje maximálně 0.8 apfu (tab. 3b). Vzhledem k této skutečnosti se majoritně jedná o kalciomikrolit s možným obsahem strukturní či molekulární „vody“ (tab. 3b).

Společně s mikrolitem byl identifikován hojný zonální fersmit s poměrem $\mathrm{Ta} /(\mathrm{Ta}+\mathrm{Nb})=0.22-0.33$ a s nízkými obsahy minoritních prvků (Ti, Zr, U, Fe, Mn; tab. 3b).

\section{Diskuse}

\section{Komplexnost zonality CGM}

$\mathrm{Nb}$-Ta oxidické minerály reprezentované převážně skupinou columbitu jsou charakteristickou akcesorickou součástí tělesa D6e, podobně jako okolních známých beryl-columbitových pegmatitů Scheibengraben (Pokorný, Staněk 1951; Novák et al. 2003), Schinderhübel I (Dostál 1966; Černý et al. 1992, 1995) aj. Obecně jsou př́tomny především v hrubě zrnité, lokálně albitizované jednotce a $v$ albitizovaném blokovém K-živci (Scheibengraben, Schinderhübel I a Bienergraben). Z albitizovaných partií blokového K-živce $\mathrm{v}$ hrubě zrnité, muskovitem bohaté jednotce byla na príkladě dvou větších krystalů CGM ( 1 $\mathrm{cm})$ demonstrována komplexnost zonálních rysů columbitu-(Mn) (obr. 3 - 4). Primární magmatické textury jsou reprezentovány dominujícím homogenním až difuzním typem a minoritně také jemnou oscilační zonalitou CGM. Vznik uvedených dvou odlišných rysů zonálnosti v měřít-

Tabulka 3a Reprezentativní analýzy CGM v hmot. \%.

\begin{tabular}{|c|c|c|c|c|c|c|c|c|}
\hline Vzorek & 1 & 1 & 2 & 2 & 1 & 1 & 2 & 2 \\
\hline Analýza & 18 & 22 & 6 & 9 & 17 & 20 & 19 & 17 \\
\hline Minerál & CGM (P) & CGM (P) & CGM $(P)$ & CGM (P) & $\operatorname{CGM}(\mathrm{S})$ & CGM (S) & CGM (S) & $\operatorname{CGM}(\mathrm{S})$ \\
\hline \multicolumn{9}{|l|}{$\overline{\text { [hm\%] }}$} \\
\hline $\mathrm{WO}_{3}$ & 0.24 & 0.24 & 0.14 & 0.11 & 0.29 & 0.21 & 0.23 & 0.15 \\
\hline $\mathrm{Ta}_{2} \stackrel{\mathrm{O}}{5}_{5}$ & 19.35 & 19.53 & 29.91 & 29.66 & 28.62 & 28.28 & 32.51 & 35.40 \\
\hline $\mathrm{Nb}_{2} \mathrm{O}_{5}$ & 59.56 & 58.83 & 48.78 & 48.89 & 50.25 & 50.55 & 46.48 & 43.95 \\
\hline $\mathrm{TiO}_{2}$ & 0.35 & 0.34 & 0.60 & 0.50 & 0.98 & 0.89 & 0.94 & 0.71 \\
\hline $\mathrm{ZrO}_{2}$ & 0.23 & 0.22 & 0.33 & 0.34 & 0.20 & 0.10 & 0.14 & 0.10 \\
\hline $\mathrm{UO}_{2}^{2}$ & 0.15 & 0.14 & 0.40 & 0.34 & 0.09 & 0.11 & 0.13 & 0.09 \\
\hline $\mathrm{Fe}_{2} \mathrm{O}_{3}$ & 1.55 & 1.62 & 1.50 & 2.22 & 1.54 & 1.46 & 1.94 & 2.22 \\
\hline $\mathrm{FeO}^{\circ}$ & 5.71 & 5.63 & 5.52 & 4.99 & 6.89 & 6.78 & 7.21 & 6.58 \\
\hline $\mathrm{MnO}$ & 12.63 & 12.50 & 11.66 & 11.82 & 10.16 & 10.27 & 9.05 & 9.70 \\
\hline $\mathrm{MgO}$ & 0.00 & 0.00 & 0.00 & 0.00 & 0.24 & 0.26 & 0.33 & 0.11 \\
\hline $\mathrm{ZnO}$ & 0.12 & 0.09 & 0.09 & 0.08 & 0.00 & 0.00 & 0.06 & 0.08 \\
\hline Suma & 99.88 & 99.15 & 98.94 & 98.96 & 99.26 & 98.91 & 99.01 & 99.09 \\
\hline \multicolumn{9}{|l|}{ [apfu] } \\
\hline$W^{6+}$ & 0.015 & 0.015 & 0.009 & 0.007 & 0.019 & 0.014 & 0.015 & 0.010 \\
\hline $\mathrm{Ta}^{5+}$ & 1.278 & 1.301 & 2.094 & 2.069 & 1.972 & 1.954 & 2.283 & 2.524 \\
\hline $\mathrm{Nb}^{5+}$ & 6.541 & 6.513 & 5.676 & 5.671 & 5.757 & 5.806 & 5.427 & 5.208 \\
\hline $\mathrm{Ti}^{4+}$ & 0.064 & 0.063 & 0.116 & 0.096 & 0.187 & 0.170 & 0.183 & 0.140 \\
\hline $\mathrm{Zr}^{4+}$ & 0.027 & 0.026 & 0.041 & 0.043 & 0.025 & 0.012 & 0.018 & 0.013 \\
\hline$U^{4+}$ & 0.008 & 0.008 & 0.023 & 0.019 & 0.005 & 0.006 & 0.007 & 0.005 \\
\hline $\mathrm{Fe}^{3+}$ & 0.283 & 0.299 & 0.290 & 0.428 & 0.293 & 0.280 & 0.377 & 0.439 \\
\hline $\mathrm{Fe}^{2+}$ & 1.159 & 1.153 & 1.189 & 1.070 & 1.459 & 1.441 & 1.557 & 1.443 \\
\hline $\mathrm{Mn}^{2+}$ & 2.599 & 2.593 & 2.542 & 2.569 & 2.182 & 2.210 & 1.980 & 2.154 \\
\hline $\mathrm{Mg}^{2+}$ & 0.000 & 0.000 & 0.000 & 0.000 & 0.091 & 0.098 & 0.127 & 0.043 \\
\hline $\mathrm{Zn}^{2+}$ & 0.022 & 0.016 & 0.017 & 0.015 & 0.000 & 0.000 & 0.011 & 0.015 \\
\hline Suma kat. & 11.996 & 11.987 & 11.997 & 11.987 & 11.990 & 11.991 & 11.985 & 11.994 \\
\hline Suma an. & 24.000 & 24.000 & 24.000 & 24.000 & 24.000 & 24.000 & 24.000 & 24.000 \\
\hline $\mathrm{Mn} /(\mathrm{Mn}+\mathrm{Fe})$ & 0.643 & 0.641 & 0.632 & 0.632 & 0.555 & 0.562 & 0.506 & 0.534 \\
\hline $\mathrm{Ta} /(\mathrm{Ta}+\mathrm{Nb})$ & 0.163 & 0.166 & 0.269 & 0.267 & 0.255 & 0.252 & 0.296 & 0.326 \\
\hline
\end{tabular}

Zkratky P/S vyjadřují primární/sekundární CGM.

Obr. 4 BSE snímky Nb-Ta oxidických minerálů z pegmatitu D6e: a-b - Konvolutně oscilačně zonální sekundární CGM lokálně nahrazované kalciomikrolitem II a fersmitem (detaily obr. 3d, h). c-g - Asociace kalciomikrolitu II a fersmitu na trhlinách columbitových krystalů. $\boldsymbol{h}$ - Reliktní místy porézní domény U-bohatého kalciomikrolitu I uzavírající relikt nerozloženého sekundárního columbitu, trhliny vyplněny v typu I a některé domény nahrazeny kalciomikrolitem II. Asociaci doplňuje nejpozdnější fersmit. 
ku krystalu columbitu-(Mn) odráží rozdíly v jeho v růstové dynamice. Relativně rovnovážný krystalový růst, daný nevýrazně fluktuujícími/kolísajícími P-T podmínkami, rovnoměrným přínosem $\mathrm{Nb}, \mathrm{Ta}, \mathrm{Mn}, \mathrm{Fe}$ a relativně pomalou difuzí iontů vede ke vzniku homogenní až difuzní textury (např. Van Lichtervelde et al. 2007; McNeil 2018). Na druhé straně vznik oscilační zonality může souviset s nevyrovnaným prínosem hlavních columbitových komponent (např. Abella et al. 1995), ale také měnícími se vnějšími činiteli (P-T parametry, ASI, Eh, pH aj.). Nicméně formování oscilační zonality může souviset také s lokálními vnitřními disturbancemi krystalového růstu nezávislými na výše zmíněných vnějších činitelích (Shore, Fowler 1996; Holten et al. 2000; Rudolph 2015).

Tabulka 3b Reprezentativní analýzy mikrolitu a fersmitu v hmot. \%, Al* je uvažován jako kontaminace vzorku a není zahrnut do vzorce mikrolitu.

\begin{tabular}{|c|c|c|c|c|c|c|c|c|}
\hline Vzorek & 2 & 2 & 2 & 1 & 2 & 1 & 2 & 2 \\
\hline Analýza & 34 & 36 & 35 & 38 & 40 & 30 & 31 & 33 \\
\hline Minerál & Mic I & Mic I & Mic (př.) & Mic II & Mic II & Fersmit & Fersmit & Fersmit \\
\hline \multicolumn{9}{|l|}{ [hm\%] } \\
\hline $\mathrm{WO}_{3}$ & 0.24 & 0.21 & 0.22 & 0.28 & 0.40 & 0.23 & 0.34 & 0.14 \\
\hline $\mathrm{Ta}_{2} \mathrm{O}_{5}$ & 50.24 & 50.57 & 53.42 & 58.37 & 56.20 & 27.73 & 36.51 & 28.56 \\
\hline $\mathrm{Nb}_{2} \mathrm{O}_{5}$ & 8.10 & 7.57 & 8.19 & 13.90 & 9.66 & 54.66 & 45.01 & 52.96 \\
\hline $\mathrm{TiO}_{2}$ & 6.54 & 6.78 & 7.18 & 3.02 & 4.61 & 0.74 & 0.75 & 1.10 \\
\hline $\mathrm{ZrO}_{2}$ & 0.00 & 0.00 & 0.05 & 0.12 & 0.14 & 0.06 & 0.11 & 0.05 \\
\hline $\mathrm{UO}_{2}$ & 17.22 & 16.64 & 18.93 & 0.50 & 2.28 & 0.18 & 0.20 & 0.58 \\
\hline $\mathrm{ThO}_{2}$ & 0.13 & 0.11 & 0.19 & 0.00 & 0.00 & 0.00 & 0.00 & 0.00 \\
\hline $\mathrm{Al}_{2} \mathrm{O}_{3}^{*}$ & 0.10 & 0.09 & 0.13 & 0.00 & 0.12 & 0.00 & 0.00 & 0.00 \\
\hline $\mathrm{Ce}_{2} \mathrm{O}_{3}$ & 0.18 & 0.26 & 0.30 & 0.18 & 0.00 & 0.10 & 0.01 & 0.10 \\
\hline $\mathrm{Fe}_{2} \mathrm{O}_{3}$ & 0.61 & 0.26 & 2.27 & 0.75 & 2.09 & - & - & - \\
\hline $\mathrm{FeO}^{3}$ & - & - & - & - & - & 0.05 & 0.18 & 0.08 \\
\hline $\mathrm{MnO}$ & 0.28 & 0.30 & 0.16 & 0.42 & 0.31 & 0.13 & 0.06 & 0.12 \\
\hline $\mathrm{CaO}$ & 12.25 & 12.51 & 1.33 & 17.67 & 17.50 & 15.52 & 15.09 & 15.41 \\
\hline $\mathrm{Na}_{2} \mathrm{O}$ & 1.77 & 1.65 & 0.00 & 0.90 & 1.41 & 0.00 & 0.01 & 0.00 \\
\hline $\mathrm{F}^{2}$ & 0.00 & 0.00 & 0.00 & 0.50 & 1.27 & 0.00 & 0.00 & 0.00 \\
\hline Suma & 97.57 & 96.86 & 92.23 & 96.11 & 94.60 & 99.41 & 98.26 & 99.09 \\
\hline \multicolumn{9}{|l|}{ [apfu] } \\
\hline$W^{6+}$ & 0.005 & 0.005 & 0.004 & 0.006 & 0.008 & 0.004 & 0.006 & 0.002 \\
\hline $\mathrm{Ta}^{5+}$ & 1.203 & 1.223 & 1.147 & 1.264 & 1.233 & 0.458 & 0.636 & 0.475 \\
\hline $\mathrm{Nb}^{5+}$ & 0.320 & 0.303 & 0.290 & 0.500 & 0.350 & 1.500 & 1.304 & 1.465 \\
\hline $\mathrm{Ti}^{4+}$ & 0.430 & 0.451 & 0.423 & 0.181 & 0.278 & 0.034 & 0.036 & 0.051 \\
\hline $\mathrm{Zr}^{4+}$ & 0.000 & 0.000 & 0.002 & 0.005 & 0.005 & 0.002 & 0.003 & 0.001 \\
\hline$U^{4+}$ & 0.335 & 0.327 & 0.330 & 0.009 & 0.041 & 0.002 & 0.003 & 0.008 \\
\hline $\mathrm{Th}^{4+}$ & 0.003 & 0.002 & 0.003 & 0.000 & 0.000 & 0.000 & 0.000 & 0.000 \\
\hline $\mathrm{Al}^{3+*}$ & 0.010 & 0.009 & 0.012 & 0.000 & 0.011 & 0.000 & 0.000 & 0.000 \\
\hline $\mathrm{Ce}^{3+}$ & 0.006 & 0.008 & 0.009 & 0.005 & 0.000 & 0.002 & 0.000 & 0.002 \\
\hline $\mathrm{Fe}^{3+}$ & 0.040 & 0.017 & 0.134 & 0.045 & 0.126 & - & - & - \\
\hline $\mathrm{Fe}^{2+}$ & - & - & - & - & - & 0.002 & 0.010 & 0.004 \\
\hline $\mathrm{Mn}^{2+}$ & 0.021 & 0.022 & 0.011 & 0.028 & 0.021 & 0.007 & 0.003 & 0.006 \\
\hline $\mathrm{Ca}^{2+}$ & 1.149 & 1.185 & 0.112 & 1.507 & 1.501 & 1.009 & 1.036 & 1.010 \\
\hline $\mathrm{Na}^{+}$ & 0.300 & 0.283 & 0.000 & 0.139 & 0.219 & 0.000 & 0.000 & 0.000 \\
\hline $\mathrm{F}^{-}$ & 0.000 & 0.000 & 0.000 & 0.126 & 0.322 & 0.000 & 0.000 & 0.000 \\
\hline Suma kat. & 3.812 & 3.826 & 2.465 & 3.689 & 3.782 & 3.020 & 3.037 & 3.024 \\
\hline Suma an. & 6.741 & 6.771 & 5.446 & 6.559 & 6.599 & 6.000 & 6.000 & 6.000 \\
\hline Suma $B$ kat. & 1.998 & 1.999 & 2.000 & 2.001 & 2.000 & - & - & - \\
\hline Suma $A$ kat. & 1.814 & 1.827 & 0.465 & 1.688 & 1.782 & - & - & - \\
\hline Vakance $A$ & 0.186 & 0.173 & 1.535 & 0.312 & 0.218 & - & - & - \\
\hline $\mathrm{Ta} /(\mathrm{Ta}+\mathrm{Nb})$ & 0.790 & 0.801 & 0.798 & 0.717 & 0.779 & 0.234 & 0.328 & 0.245 \\
\hline
\end{tabular}

Zkratky Mic I/II vyjadřují generaci mikrolitu I resp. II a „(př.)“ - přechodný člen mikrolitu mezi typem I a II.

Tabulka 4 Přehled velikostí poměrů $M n /(M n+F e)$ a Ta/(Ta+Nb) pro primární CGM $(P)$ a sekundární CGM (S), pro mikrolit I/II a fersmit udán poměr $\mathrm{Ta} /(\mathrm{Ta}+\mathrm{Nb})$.

\begin{tabular}{lccccc}
\hline & CGM $(\mathrm{P})$ & CGM $(\mathrm{S})$ & mikrolit I & mikrolit II & fersmit \\
\hline $\mathrm{Mn} /(\mathrm{Mn}+\mathrm{Fe})$ & $0.50-0.67$ & $0.36-0.64$ & - & - & - \\
$\mathrm{Ta} /(\mathrm{Ta}+\mathrm{Nb})$ & $0.16-0.36$ & $0.25-0.50$ & $0.79-0.80$ & $0.72-0.84$ & $0.22-0.33$ \\
\hline
\end{tabular}


Primární magmatická zonalita podlehla rozsáhlé rekrystalizaci in situ vlivem prínosu pozdně-magmatických až post-magmatických fluid. Rekrystalizační proces zahrnuje mnohonásobné opakování dílčího rozpouštění (koroze) a opětovné precipitace (dissolution-reprecipitation) krystalů columbitu vedoucí ke vzniku komplexních sekundárních typů zonálnosti označovaných jako skvrnitá zonalita (patchy zoning) a také běžně se vyskytující sekundární konvoluční oscilační zonálnosti (obr. 3 - 4). Uvedené fenomény $v$ CGM byly popsány na mnoha vzácnoprvkových pegmatitech (např. Lahti 2000; Van Lichtervelde et al. 2007; Rao et al. 2009; Chudík et al. 2011; Alfonso et al. 2018; Novák et al. 2018), včetně beryl-columbitových pegmatitů studované oblasti Maršíkova (Černý et al. 1992; Novák et al. 2003), nicméně mechanismus jejich vzniku je stále předmětem diskuse (např. Holten et al. 2000; Rudolph 2015).

Proměnné $\mathrm{Ta} /(\mathrm{Ta}+\mathrm{Nb})$ a $\mathrm{Mn} /(\mathrm{Mn}+\mathrm{Fe})$ : indikátory magmatického versus hydrotermálního vývoje $\mathrm{Nb}-\mathrm{Ta}$ mineralizace

Variace poměrů $\mathrm{Ta} /(\mathrm{Ta}+\mathrm{Nb})$ a $\mathrm{Mn} /(\mathrm{Mn}+\mathrm{Fe})$ v CGM, rutilu, wolframitu aj. představují vhodné nepřímé indikátory stupně frakcionace mateřských hornin, ale také indikátory charakteru fluid (Černý et al. 1985, 1986; Van Lichtervelde et al. 2007, 2018; Wise et al. 2012; Melcher et al. 2015). Primární columbity se vyznačují v rámci obou studova-

a

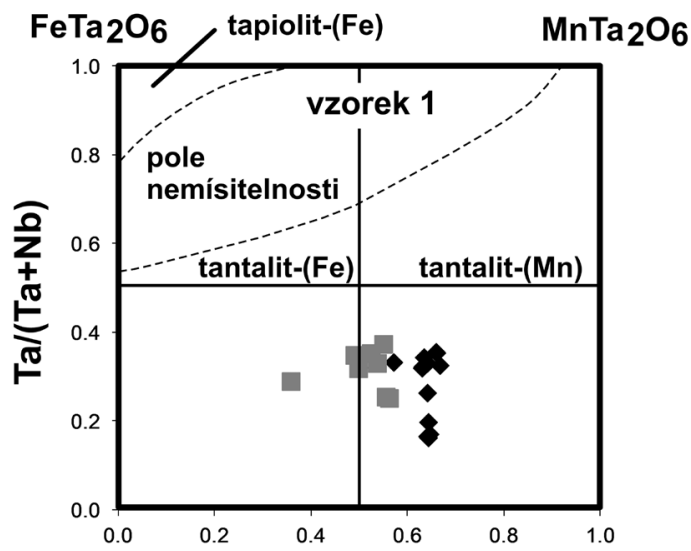

b

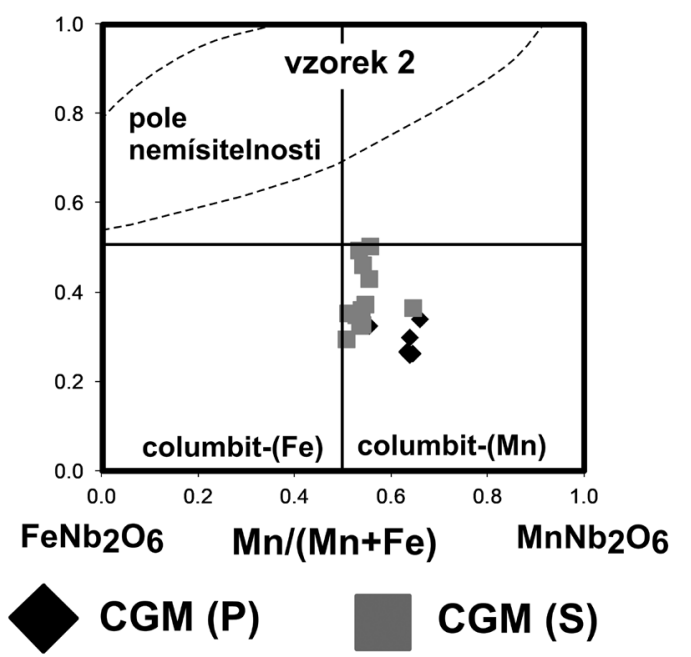

Obr. 5 a-b. Klasifikační diagramy pro primární $(P)$ a sekundární (S) minerály skupiny columbitu ze studovaných vzorků z pegmatitu D6e. ných vzorků značně limitovaným rozsahem obou poměrů $[\mathrm{Mn} /(\mathrm{Mn}+\mathrm{Fe})=0.50-0.67 ; \mathrm{Ta} /(\mathrm{Ta}+\mathrm{Nb})=0.16-0.36 ; \mathrm{tab}$. 3a a 4, obr. 5]. Primární (magmatický) subvertikální trend silně omezený polem columbitu-( $\mathrm{Mn}$ ) není dosud $\mathrm{z}$ berylových pegmatitů v okolí Maršíkova znám (srovnej obr. 7). Nižší stupeň frakcionace $\mathrm{Ta} / \mathrm{Nb}$ ve skupině columbitu byl zjištěn pouze $v$ prípadě relativně $\mathrm{Nb}$ a Ti-obohaceného pegmatitu na Lysé hoře (Chládek, Zimák 2016). Na druhé straně středně vysoké Mn-obohacení columbitu-(Mn) uvedený pegmatit (D6e) približuje ke geochemicky více vyvinutým pegmatitům Bienergraben, Schinderhübel I a Scheibengraben (Černý et al. 1992, 1995; Novák 2005; Novák et al. 2003), které se však vyznačují i prrítomností Ta-dominantních minerálů: tantalitu-(Mn) a lokálně tapiolitu-(Fe) (Scheibengraben; Pokorný, Staněk 1951).

$\checkmark$ minulosti byla zjištěna stabilita poměru $\mathrm{Ta} /(\mathrm{Ta}+\mathrm{Nb})$ v primárních a sekundárních $\mathrm{Nb}$, Ta-minerálech při přechodu z magmatické do hydrotermální etapy vývoje mateřského pegmatitu (Černý et al. 1985, 1986; Novák, Černý 1998). Novější práce ale ukázaly v některých vzácnoprvkových pegmatitech reverzní vývoj CGM v jednom či obou poměrech $\mathrm{Ta} /(\mathrm{Ta}+\mathrm{Nb})$ a $\mathrm{Mn} /(\mathrm{Mn}+\mathrm{Fe})$ (např. Wang et al. 1997; Chudík et al. 2011; Neiva et al. 2015; Alfonso et al. 2018). Pegmatitová tavenina, generující těleso D6e byla relativně obohacená $\mathrm{Nb}$ a $\mathrm{Mn}$, jak dokládá $\mathrm{Ta} /$ $(\mathrm{Ta}+\mathrm{Nb}) \leq 0.36$ a $\mathrm{Mn} /(\mathrm{Mn}+\mathrm{Fe}) \sim 0.67$ u primárního colum-

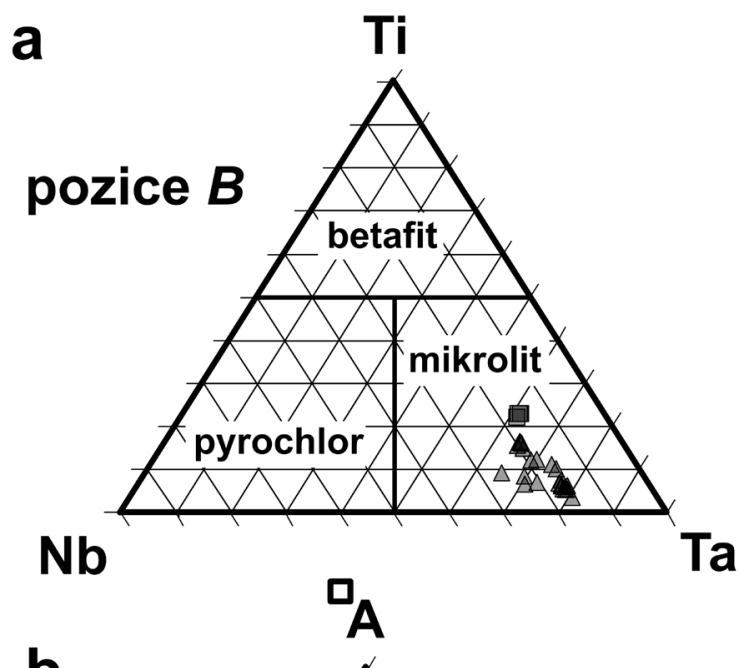

b

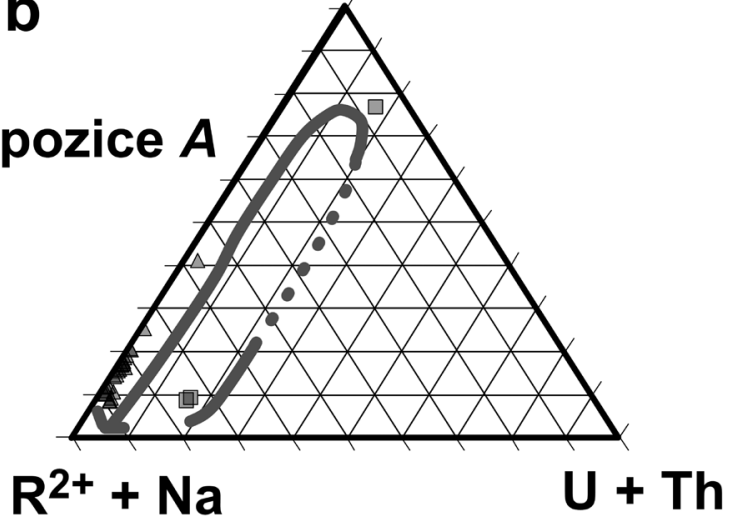
mikrolit I mikrolit II

Obr. 6 Ternárni diagramy graficky ilustrující zastoupení koncových členů minerálů superskupiny pyrochloru. a - strukturní pozice B. $\boldsymbol{b}$ - Strukturní pozice A s vyznačením trendu vývoje chemického složení. 
bitu-(Mn). Nicméně sekundární, texturně již nepochybně post-magmatický columbit s komplexními rekrystalizačními texturami (obr. 3 - 4) se vyznačuje více či méně výraznými posuny složení v obou poměrech na příkladu obou studovaných vzorků columbitu: $\mathrm{Mn} /(\mathrm{Mn}+\mathrm{Fe})=0.36-0.64$ a $\mathrm{Ta} /(\mathrm{Ta}+\mathrm{Nb})=0.25-0.50$ (obr. 5, tab. 4). Podobný vývoj daný růstem $\mathrm{Ta} /(\mathrm{Ta}+\mathrm{Nb})$, poklesem $\mathrm{Mn} /(\mathrm{Mn}+\mathrm{Fe})$, ale naopak růstem $\mathrm{Ti}$ v sekundárních CGM popisují například Neiva et al. (2015) v lepidolitovém subtypu pegmatitů v oblasti Gouveia v Portugalsku.

Ve finální části hydrotermální etapy vývoje $\mathrm{Nb}$-Ta mineralizace dochází k výraznému rozptylu hodnot $\mathrm{Ta} /(\mathrm{Ta}+\mathrm{Nb})$ vlivem krystalizace mikrolitu [Ta/(Ta+Nb) 0.84] a fersmi$\mathrm{tu},[\mathrm{Ta} /(\mathrm{Ta}+\mathrm{Nb}) \leq 0.33]$. Uvedené fluktuace ve smyslu Ta/ $(\mathrm{Ta}+\mathrm{Nb})$ mohou být způsobeny odlišnou mobilitou $\mathrm{Nb}$ a Ta (Van Lichtervelde et al. 2007), popř́padě jejich selektivním výnosem z hydrotermálního systému. Fluidy řizená alterace CGM a jiných primárních minerálů (např. zirkon, živce, beryl, muskovit) mohla vést $\mathrm{k}$ uvolnění $\mathrm{Ca}, \mathrm{Na}, \mathrm{U}$, $\mathrm{F}$, ale také $\mathrm{Ta}, \mathrm{Nb}$ a Ti. Kalciomikrolit I (chemismem blízký U-bohatého kalciomikrolitu z Schinderhübelu I - Černý et al. 1992) inkorporuje do pozice $B$ zvýšený obsah Ti (s $7.2 \mathrm{hm} . \% \mathrm{TiO}_{2}$; $\sim 0.42$ apfu Ti), v pozici $A$ dominuje Ca, ale obsahy $\mathrm{U}$ vzrůstají až k $19 \mathrm{hm}$. \% UO $\mathrm{UO}_{2}(0.33$ apfu U; tab. 3b). Vysoký obsah Ti může souviset s alterací primárního/sekundárního columbitu (obsahujícího $\leq 1.4 \mathrm{hm}$. $\% \mathrm{TiO}_{2}$ ) anebo minoritně prítomného biotitu. Typ I podléhá rozsáhlé alteraci a rekrystalizaci na přechodný člen (obr. 6b), ale zejména na převládající typ II. Skrze alteraci kalciomikrolitu I na přechodný člen (obr. 6b) dochází ke značné ztrátě $\mathrm{Ca}$ a $\mathrm{Na}$ a značnému zvýšení zastoupení skupiny s nulovým nábojem $v$ pozici $A$ (tab. 3b). Alterace kalciomikrolitu I zahrnuje pravděpodobné uplatnění vnitřních (radioaktivní rozpad uranu) a vnějších činitelů (předpokládaná hydratace). Hojnost trhlin v určitých doménách zrn typu I může být způsobena rostoucím vnitřním tlakem vlivem radioaktivního rozpadu uranu (Ewing 1994; Duran et al. 2016; Zietlow et al. 2017). Uvedené texturní fenomény $v$ prípadě $U$, Th-obohacených minerálů jsou častým jevem u thoritu, zirkonu (Seydoux-Gu-

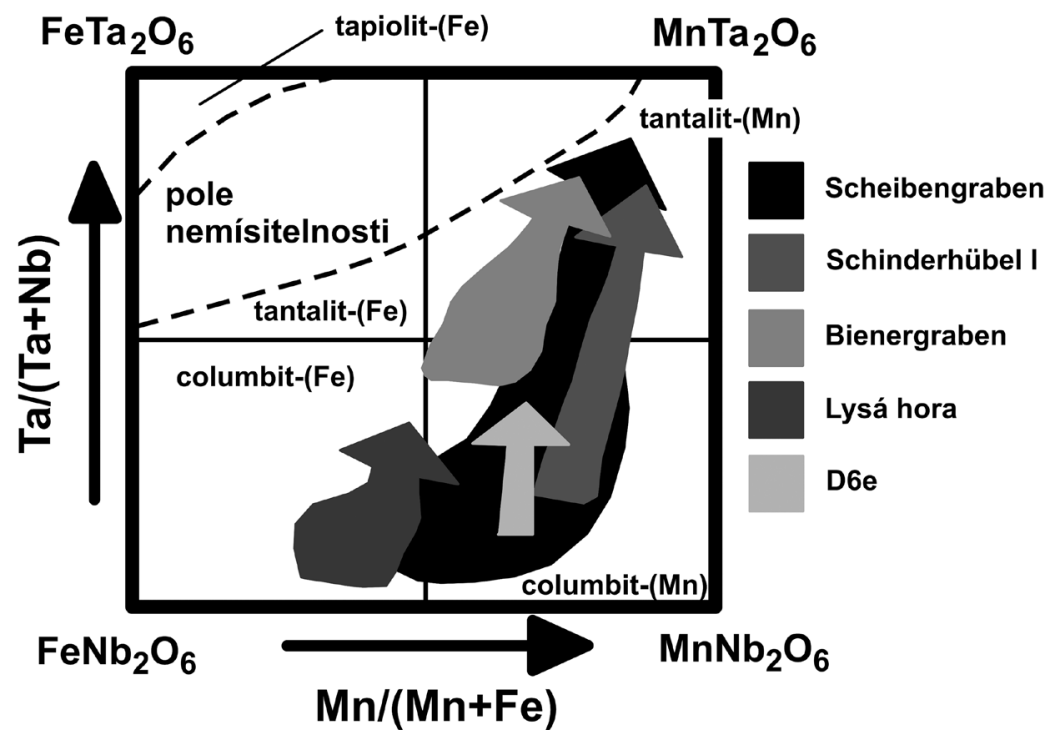

Obr. 7 Evoluční Ta/(Ta+Nb) versus $M n /(M n+F e)$ trendy primárně magmatických CGM pro studovaný pegmatit D6e a okolní beryl-columbitové pegmatity v oblasti Maršíkova (Černý et al. 1992; Novák et al. 2003; Chládek, Zimák 2016; Chládek et al. in prep.). illaume et al. 2012, 2015) nebo euxenitu (Škoda, Novák 2007). U, Th-bohaté PSGM podléhají sekundárním alteracím (především hydrataci) mnohem snáze než jejich krystalické ekvivalenty (Geisler et al. 2005; Bonazzi et al. 2006; Loun et al. 2018). Kalciomikrolit II lokálně vyplňuje trhliny v doménách typu I (obr. 4h), ale ve většině prípadů byl typ II zjištěn na trhlinách primárního i sekundárního columbitu. Vzhledem k nižším analytickým sumám mikrolitů je možná prítomnost „vody“ [ve formě $(\mathrm{OH})^{-}$nebo $\mathrm{H}_{2} \mathrm{O}$ ], která však nebyla analyticky stanovena. Hydratace minerálů pyrochlorové superskupiny je obecně známým faktem vedoucím ke značnému vyloužení $A$, poprípadě Y-iontů (např. Lumpkin et al. 1986; Lumpkin, Ewing 1992, 1995, 1996; Geisler et al. 2004; Duran et al. 2016). Krystalizace kalciomikrolitu II a fersmitu představuje finální fázi hydrotermálního vývoje studované mineralizace. Kalciomikrolit II je zřetelně obohacen $\mathrm{Ta}, \mathrm{Ca}, \mathrm{Na}$, ale také $\mathrm{F}$. Sekundární mikrolity obsahují obyčejně nízké koncentrace fluoru (např. Lumpkin a Ewing 1992; Loun et al. 2018), na druhé straně evidentně sekundární (postmagmatické) mikrolity z beryl-columbitových pegmatitů ze Západních Tater obsahují až 3 hm. \% F (Chudík, Uher 2009; Chudík et al. 2011). Zvýšené obsahy F v kalciomikrolitu II (do $1.45 \mathrm{hm} . \%$ ) pravděpodobně souvisí s alterací primárních minerálů, obohacených $\mathrm{F}$ (hlavně muskovit). Nízký obsah $\mathrm{U} v$ typu II $\left(\leq 2.7 \mathrm{hm}\right.$. \% $\left.\cup_{2}\right)$ poukazuje na značnou remobilizaci $U$ a jeho únik a následnou možnou vazbu do jiného nespecifikovaného sekundárního minerálu. $\mathrm{Na}$ druhé straně fersmit se vyznačuje optimální stechiometrií blízkou $A B_{2} \mathrm{O}_{6}$ s dominantním Ca v pozici $A$ a obecně nízkými proporcemi minoritních prvků.

\section{Závěr}

Pegmatitové těleso D6e reprezentuje mineralogicky zajímavý beryl-columbitový granitový pegmatit v prostoru Maršíkova. Homogenní až oscilačně zonální magmatická zonalita a dále rekrystalizační, nepravidelně zonální skvrnité až konvolutně oscilační textury poukazují na komplikovanost procesů při formování CGM během krystalizace pegmatitové taveniny a během následné interakce CGM $\mathrm{s}$ postmagmatickými fluidy. Primární magmatický trend ve smyslu $\mathrm{Ta} /(\mathrm{Ta}+\mathrm{Nb})$ a $\mathrm{Mn} /(\mathrm{Mn}+\mathrm{Fe})$ je omezen na pole columbitu-(Mn) a obě frakcionace $\mathrm{Mn} / \mathrm{Fe}$ i $\mathrm{Ta} / \mathrm{Nb}$ jsou významně limitovány ve srovnání $\mathrm{s}$ geochemicky vyvinutějšími pegmatity Scheibengraben, Schinderhübel I anebo Bienergraben. Formování sekundárních CGM vyznačujících se mírně rostoucími obsahy $\mathrm{Fe}$ a Ta poukazuje na prínos fluid, které v procesu částečného rozpouštění a následné reprecipitace způsobily redistribuci $\mathrm{Nb}, \mathrm{Ta}$, $\mathrm{Mn}$ a Fe v rámci CGM vedoucí lokálně k částečnému selektivnímu odnosu $\mathrm{Mn}$ a $\mathrm{Nb}$. Mobilita fluidně remobilizovaných prvků (např. $\mathrm{Ca}, \mathrm{Na}, \mathrm{U}, \mathrm{F}) \mathrm{z}$ alterovaných magmatických minerálů (např. živce, beryl, muskovit, zirkon, CGM) byla lokálně stabilizována následnou krystalizací kalciomikrolitu a fersmitu, ale $s$ největší pravděpodobností také sekundárních Be-minerálů (milarit, sekundární beryl, bertrandit), vznikajících komplexními alteracemi a rekrystalizacemi berylu. 


\section{Poděkování}

Autoři by rádi vyjádrìli srdečný dík Vieře Kollárové za analytickou práci na elektronové mikrosondě na ŠGúDŠ $\checkmark$ Bratislavě a dále za cenné rady a pripomínky recenzentům Milanu Novákovi a Radku Škodovi, jejichž kritické poznámky zvýšily kvalitu príspěvku. Tato práce byla podpořena projektem Agentury na podporu výzkumu a vývoje APVV-14-0278, projekty VEGA-1/0499/16 a VEGA1/007915 Ministerstva školství, vědy, výzkumu a sportu Slovenské republiky a projektem SGS SP 2019/77 Ministerstva školství, mládeže a tělovýchovy České republiky.

\section{Literatura}

Abella PA, Corbella M, Melgarejo JC (1995) Nb-Ta- minerals from the Cap de Creus pegmatite field, eastern Pyrenees: distribution and geochemical trends. Mineral Petrol 55: 53-69

Alfonso P, Hamid SA, Garcia-Valles M, Llorens T, López Moro FJ, Tomasa O, Calvo D, Guasch E, Anticol H, Oliva J, Parcerisa F, García Polonio G (2018) Textural and mineral-chemistry constraints regarding the columbite-group minerals in the Penouta deposit: evidences of magmatic and fluid-related processes. Mineral Petrol 82: 199-222

Atencio D, Andrade MB, Christy AG, Gieré R, Kartashov PM (2010) The pyrochlore supergroup of minerals: Nomenclature. Can Mineral 48: 673-698

Badanina EV, Sitnikova MA, Gordienko VV, Melcher F, GÄBleR HE, LodziaK J, SYRITSO LF (2015) Mineral chemistry of columbite-tantalite from spodumene pegmatites of Kolmozero, Kola Peninsula (Russia). Ore Geol Rev 64: 720-735

BonazzI P, Bindi L, Zoppi M, Capitani GC, Olmı F (2006) Single-crystal diffraction and transmission electron microscopy studies of "silicified" pyrochlore from Narssârssuk, Julianehaab district, Greenland. Am Mineral 91: 794-801

ČERný P, Meintzer RE, Anderson AJ (1985) Extreme fractionation in rare-element granitic pegmatites: selected examples of data and mechanisms. Can Mineral 23: 381-421

Černý P, Goad BE, Hawthorne FC, Chapman R (1986) Fractionation trends of the $\mathrm{Nb}$ - and Ta-bearing oxide minerals in the Greer Lake pegmatitic granite and its pegmatite aureole, southeastern Manitoba. Am Mineral 71: 501-517

ČERNÝ P, ERCIT TS (2005) The classification of granitic pegmatites revisited. Can Mineral 43: 2005-2026

Černý P, Novák M, Chapman R (1992) Effects of sillimanite-grade metamorphism and shearing on $\mathrm{Nb}$, Ta-oxide minerals in granitic pegmatites: Maršíkov, northern Moravia, Czechoslovakia. Can Mineral 30: 699-718

Černý P, Novák M, Chapman R (1995) The Al (Nb,Ta) Ti substitution in titanite: the emergence of a new species? Mineral Petrol 52: 61-73

CHÁB J, StRÁNíK Z, ELIÁŠ M (2007) Geological map of the Czech Republic 1 : 500 000. Czech Geological Survey, Prague, Czech Republic

CHLÁDEK Š, ZIMÁK J (2016) Association of Nb-Ta-(Ti-REE) oxide minerals in the Maršíkov - Lysá Hora pegmatite in Hrubý Jeseník Mountains, Czech Republic. Bull mineral-petrolog Odd Nár Muz (Praha) 24: 25-32

Christy AG, Atencio D (2013) Clarification of status of species in the pyrochlore supergroup. Mineral Mag. 77: $13-20$
CHudík P, Uher P (2009) Minerály skupiny pyrochlóru z granitových pegmatitov Západných Karpát: variácie chemického zloženia a substitučné mechanizmy. Mineral. Slov. 41: 159-168

Chudí P, Uher P, Gadas P, Škoda R, PršEk J (2011) Niobium-tantalum oxide minerals in the Jezuitske Lesy granitic pegmatite, Bratislava Massif, Slovakia: $\mathrm{Ta}$ to $\mathrm{Nb}$ and $\mathrm{Fe}$ to $\mathrm{Mn}$ evolutionary trends in a narrow Be,Cs -rich and Li,B-poor dike. Mineral Petrol 102: 15-27

DostÁL J (1966) Mineralogische und Petrographische Verhältnisse von Chrysoberyll-Sillimanit Pegmatit von Maršíkov. Acta Univ Carol, Geol 4: 271-287

Duran ChJ, Seydoux-Guillaume AM, Bingen B, Gouy S, Parseval P, Ingrin J, Guillaume D (2016) Fluid-mediated alteration of (Y,REE,U,Th)-(Nb,Ta,Ti) oxide minerals in granitic pegmatite from the Evje-Iveland district, southern Norway. Mineral Petrol 110: 581-599

ERCIT TS (1994) The geochemistry and crystal chemistry of columbite-group minerals from granitic pegmatites, southwestern Grenville Province, Canadian Shield. Can Mineral 32: 421-438

EWING RC (1994) The metamict state: 1993 the centennial. Nuclear Instrum Methods Phys Res 91: 22-29

Geisler T, Berndt J, Meyer HW, Pollok K, Putnis A (2004) Low-temperature aqueous alteration of crystalline pyrochlore: correspondence between Nature and experiment. Mineral Mag. 68: 905-922

Geisler T, Seydoux-Guillaume AM, Poeml P, Golla-Schindler U, Berndt J, Wirth R, Pollok K, Janssen A, PutNIS A (2005) Experimental hydrothermal alteration of crystalline and radiation-damaged pyrochlore. J Nucl. Mater. 344: 17-23

Hegner E, KRÖner A (2000) Review of Nd isotopic data and xenocrystic and detrital zircon ages from the pre -Variscan basement in the eastern Bohemian Massif: speculations on palinspatic reconstruction. In: Franke W (ed) Orogenic Processes: Quantification and Modelling in the Variscan Belt. Geological Society, Special Publications, London: 113-129

Holten T, Jamtveit B, Meakin P (2000) Noise and oscillatory zoning of minerals. Geochim Cosmochim Acta 64: 1893-1904

Janoušek V, Aichler J, Hanžl P, Gerdes A, ERban V, Ž́ă̌ek V, Pecina V, Pudilová M, Hrdičková K, Mixa P, ŽáčKOVÁ E (2014) Constraining genesis and geotectonic setting of metavolcanic complexes: a multidisciplinary study of the Devonian Vrbno Group (Hrubý Jeseník Mts., Czech republic). Int J Earth Sci 103: 455-483

Kröner A, O’Brien PJ, Nemchin AA, Pidgeon RT (2000) Zircon ages for high pressure granulites from South Bohemia, Czech Republic, and their connection to Carboniferous high temperature processes. Contrib Mineral Petrol 138: 127-142

KruŤa T, Paděra K, Pouba Z, Sládek R (1968) Die Mineralparagenese in dem mittleren Teile des Altvatergebirges (Hrubý Jeseník, Hohe Gesenke, ČSSR). Čas Mor Mus 53: 5-80

LAHTI SI (2000) Compositional variation in columbitegroup minerals from different types of granitic pegmatites of the Eräjärvi district, South Finland. J Czech Geol Soc 45: 107-118

Loun J, Novák M, Cempírek J, Škoda R, Vašinová Galiová M, Prokeš L, Dosbaba M, Čopjaková R (2018) Geochemistry and secondary alterations of microlite from eluvial deposits in the Numbi mining area, S. Kivu, Democratic Republic of the Congo. Can Mineral 56: 1-18 
LUMPKIN GR, Chakoumakos BC, EwING RC (1986) Mineralogy and radiation effects of microlite from the Harding pegmatite, Taos County, New Mexico. Am Mineral 71: 569-588

LUMPKIN GR, EwING RC (1992) Geochemical alteration of pyrochlore group minerals: Microlite subgroup. Am Mineral 77: 179-188

LUMPKIN GR, EwING RC (1995) Geochemical alteration of pyrochlore group minerals: Pyrochlore subgroup. Am Mineral 80: 732-743

LUMPKIN GR, EwING RC (1996) Geochemical alteration of pyrochlore group minerals: Betafite subgroup. Am Mineral 81: 1237-1248

MCNEIL AG (2018) Crystallization processes and solubility of columbite-(Mn), tantalite-(Mn), microlite, pyrochlore, wodginite and titanowodginite in highly fluxed haplogranitic melts. Dizertační práce, University of Western Ontario: $393 \mathrm{~s}$

Melcher F, Graupner T, Gäbler He, Sitnikova M, Henjes -Kunst F, Oberthür T, Gerdes A, Dewaele S (2015) Tantalum - (niobium - tin) mineralisation in African pegmatites and rare metal granites: Constraints from $\mathrm{Ta}-\mathrm{Nb}$ oxide mineralogy, geochemistry and $\mathrm{U}-\mathrm{Pb}$ geochronology. Ore Geol Rev 64: 667-719

MIKULSKI SZ, WILLIAMS IS, BAgIŃSKI B (2013) Early Carboniferous (Viséan) emplacement of the collisional Kłodzko-Złoty Stok granitoids (Sudetes, SW Poland): constraints from geochemical data and zircon $\mathrm{U}-\mathrm{Pb}$ ages. Int J Earth Sci 102: 1007-1027

Neiva AMR, Gomes CL, Silva PB (2015) Two generations of zoned crystals of columbite-group minerals from granitic aplite-pegmatite in the Gouveia area, central Portugal. Eur J Mineral 27: 771-782

NovÁk M (1988) Granáty z pegmatitů Hrubého Jeseníku (severní Morava). Acta Mus Moraviae, Sci nat 73: 3-28

NovÁk M (2005) Granitické pegmatity Českého masívu (Česká republika); mineralogická, geochemická a regionální klasifikace a geologický význam. Acta Mus Moraviae, Sci geol 90: 3-74

Novák M, REJL L (1993) Vztah muskovitických pegmatitů ke geofyzikálním polím v oblasti Hrubého Jeseníku. Acta Mus Moraviae, Sci nat 77: 49-61

Novák M, ČERnÝ P (1998) Niobium - Tantalum oxide minerals from complex granitic pegmatites in the Moldanubicum, Czech Republic: Primary versus secondary compositional trends. Can Mineral 36: 659-672

NovÁK M, ČERnÝ P, Uher P (2003) Extreme variation and apparent reversal of $\mathrm{Nb}-\mathrm{Ta}$ fractionation in columbite-group minerals from the Scheibengraben beryl-columbite pegmatite, Maršíkov, Czech Republic. Eur J Mineral 15: 565-574

Novák M, Chládek Š, Uher P, Gadas P (2018) Complex magmatic and subsolidus compositional trends of columbite-tantalite in the beryl-columbite Šejby granitic pegmatite, Czech Republic: role of crystal-structural constraints and associated minerals. J Geosci 63: 253-263

Pokorný J, StanĚk J (1951) Berylový pegmatit ze Scheiengraben u Maršíkova. Práce Moravskoslez Akad, Vědy Prír 7: 247-258

Pouchou JL, PICHOIR F (1985) "PAP" (phi-rho-z) procedure for improved quantitative microanalysis. In: Armstrong, JT (ed) Microbeam Analysis. San Francisco Press, San Francisco: 104-106
Rao C, Wang RCh, Hu H, Zhang WL (2009) Complex internal textures in oxide minerals from the Nanping No. 31 dyke of granitic pegmatite, Fujian province, Southeastern China. Can Mineral 47: 1195-1212

RUdOLPH P (2015) Handbook of crystal growth, Vol. II. Elsevier 1-43

Schulmann K, GAYeR R (2000) A model for continental acrectionary wedge developed by oblique collision: the NE Bohemian Massif. J Geol Soc London 157: 401-416

Schulmann K, Oliot E, Košuličová M, Montigny R, ŠtipSKÁ P (2014) Variscan thermal overprints exemplified by U-Th-Pb monazite and K-Ar muscovite and biotite dating at the eastern margin of the Bohemian Massif (East Sudetes, Czech Repubic). J Geosci 59: 389-413

Seydoux-Guillaume AM, Montel JM, Bingen B, Bosse V, Parseval P, Paquette JL, Janots E, Wirth R (2012) Low-temperature alteration of monazite: fluid mediated coupled dissolution-precipitation, irradiation damage, and disturbance of the $\mathrm{U}-\mathrm{Pb}$ and $\mathrm{Th}-\mathrm{Pb}$ chronometers. Chem Geol 330-331: 140-158

Seydoux-Guillaume AM, Bingen B, Paquette Jl, Bosse V (2015) Nanoscale evidence for uranium mobility in zircon and the discordance of $\mathrm{U}-\mathrm{Pb}$ chronometers. Earth Planet Sci Lett 409: 43-48

SHORE M, FoWleR AD (1996) Oscillatory zoning in minerals: a common phenomenon. Can Mineral 34: 11111126

ŠKodA R, NovÁK M (2007): Y,REE,Nb,Ta,Ti-oxide $\left(\mathrm{AB}_{2} \mathrm{O}_{6}\right)$ minerals from REL-REE euxenite-subtype pegmatites of the Třebíč Pluton, Czech Republic; substitutions and fractionation trends. Lithos 95: 43-57

Van Lichtervelde MV, Salvi S, Beziat D (2007) Textural features and chemical evolution in tantalum oxides: magmatic versus hydrothermal origins for Ta mineralization in the Tanco Lower Pegmatite, Manitoba, Canada. Econ Geol 102: 257-276

Van Lichtervelde MV, Holtz F, Melcher F (2018) The effect of disequilibrium crystallization on $\mathrm{Nb}$-Ta fractionation in pegmatites: Constraints from crystallization experiments of tantalite-tapiolite. Am Mineral 103: 1401-1416

Wang RC, Fontan F, Xu SJ, Chen XM (1997) The association of columbite, tantalite and tapiolite in the Suzhou granite, China. Can Mineral 35: 699-706

WISE MA, Francis CA, Černý P (2012) Compositional and structural variations in columbite-group minerals from granitic pegmatites of the Brunswick and Oxford fields, Maine: differential trends in F-poor and F-rich environments. Can Mineral 50: 1515-1530

Zachovalová K, Leichmann J, Švancara J (2002) Žulová Batolith: a post-orogenic, fractionated ilmenite-allanite I-type granite. J Czech Geol Soc 47: 1-2

Zietlow P, Beirau T, Mihallova B, Groat LA, Chudy T, Shelyug A, Navrotsky A, Ewing RC, Schlütter J, ŠKoda R, BISMAYER U (2017) Thermal annealing of natural, radiation-damaged pyrochlore. Z Kristallogr - Crystalline Materials 232: 25-38

ZıмÁK J (2013) Uran a thorium v granitických pegmatitech a aplitech silezika. Geol Výzk Mor Slez 2012: 162-166 